RESEARCHARTICLE

\section{Relationships with Teachers and Achievement Motivation in the Context of the Transition to Secondary School}

\author{
Roch Chouinard ${ }^{1 *}$, Normand Roy ${ }^{1}$, Isabelle Archambault ${ }^{1}$, and Jonathan Smith ${ }^{1}$ \\ ${ }^{1}$ Université de Montréal, Montreal, Quebec, Canada \\ ${ }^{2}$ Université du Québec à Trois-Rivières, Trois-Rivieres, Quebec, Canada
}

\begin{abstract}
The present study examined the link between students' relationships with teachers and achievement motivation in the context of the transition to secondary school. Participants were 323 French-speaking students from various public schools of the Province of Quebec (Canada). A self-reported questionnaire measuring students' appreciation of their relationships with teachers as well as their competence beliefs, utility value, interest, and achievement goals (mastery, performance-approach and work-avoidance) was administered to participants immediately before and after their transition to secondary school. Growth curve analyses indicate that, following the transition to secondary school, participants experienced a decline of achievement motivation. Results further show that students' achievement motivation co-varied with their relationships with teachers, before and after the transition to secondary school. For instance, students' who improved their relationships with teachers following this transition also reported a lower motivational decrease. These results highlight the need for schools to emphasize students' relationships with their teachers in order to facilitate the transition to secondary school.
\end{abstract}

\section{G Open Access}

Citation: Chouinard, R., Roy, N., Archambault, I., Smith, J. (2017). Relationships with Teachers and Achievement Motivation in the Context of the Transition to Secondary School. Interdisciplinary Education and Psychology, 2(1):1.

Received: August 1, 2017

Accepted: November 13, 2017

Published: November 28, 2017

Copyright: @ 2017 Chouinard et al. This is an open access article distributed under the terms of the Creative Commons Attribution License, which permits unrestricted use, distribution, and reproduction in any medium, provided the original author and source are credited.

\section{Corresponding author:}

Roch Chouinard, Université de Montréal, Département de psychopédagogie et d'andragogie, Montreal, QC, Canada. E-mail: roch.chouinard@umontreal.ca

\section{Keywords}

Achievement motivation, student-teachers, relationships, school transition

\section{Introduction}

Motivation is widely known to be associated with student engagement and school success (Bandura, 1997, Hardré, 2015; Wigfield, Cambria, \& Eccles, 2012). Many researchers have documented a reduction in students' achievement motivation across the school years (Chouinard \& Roy, 2008; Jacobs, Lanza, Osgood, Eccles, \& Wigfield, 2002; Watt, 2004) and especially after the transition to secondary school (Dotterer, McHale, \& Crouter, 2009; Duchesne, Ratelle, \& Feng, 2014; Gottfried, Fleming, \& Gottfried, 2001; Zanobini \& Usai, 2002). However, although research generally underlines that the transition from elementary to secondary school is deemed to be a stressful event that can undermine students' motivation, most of these studies also stated that some students do not seem to be affected that much (Jozsa \& Morgan, 2014; Ratelle, Guay, Larose, \& Senécal, 2004; Tonkin \& Watt, 2003). How can we explain these differences? Studies did not provide a valid answer to this question yet, but the quality of the relationships students share with their teachers during that period might be part of the answer.

Motivation is a key factor in students' learning process, which contributes to their academic achievement. This is well-recognized in established theoretical models, such as the Expectancy-Value theory (Wigfield, Eccles, Schiefele, Roeser, \& Davis-Kean) and the Achievement Goals theory (Ames, 1992; Dweck, 1992; Nicholls, 1984).

Inspired by the socio-cognitive approach, the Expectancy-Value theory has been widely used over the last decades to conceptualize the development of achievement motivation. 
According to the modern version of this theory, engagement and achievement are best predicted by the combination of students' expectations of success and subjective task value (Wigfield et al., 2015; Wigfield et al, 2009). The Expectancy component corresponds to the beliefs students hold about how well they will perform on an upcoming task and relates to their perception of being able to carry out their academic projects successfully. Expectancy appears to be influenced by specific beliefs such as competence beliefs which refer to the assessment done by the children themselves of their skills and capability to perform well in a specific domain (Eccles et al., 1993). The Value component refers to the intrinsic significance, utility, attainment value, and cost students ascribed to a given task, a school subject or school in general (Wigfield, Muensks, \& Rosenzweig, 2015). On one side, intrinsic value refers to interest and immediate enjoyment derived from engagement, while attainment value is the importance of tasks and academic achievement for the individual. On the other side, utility value concerns how a task or a student's academic achievement is related to his current and future goals. Finally, cost is defined as the negative aspects of engaging in a task, such as pessimistic emotions and effort (Eccles \& Wigfield, 2002). In the present study, we investigated how students change across the transition to secondary school along three of the most central components of the Expectancy-Value theory: competence beliefs, utility value and interest.

Goals theory suggested originally the existence of two general goal orientations: mastery and performance goals (Ames, 1992; Dweck, 1992; Nicholls, 1984). Students presenting a mastery goals orientation place great importance on learning and understanding, whereas students presenting a performance goals orientation focus on demonstrating their competence in relation to others (Elliot, Murayama, \& Pekrun, 2011). Nevertheless, some researchers have produced evidence stating students' performance goals maydiffer according to their self-perceptions (Bouffard, Boisvert, Vezeau, \& Larouche, 1995). As a result, many authors now view achievement goals theory from an approach-avoidance viewpoint (Harackiewicz, Barron, Pintrich, Elliot \& Trash, 2002; Wigfield et al., 2015). In this line, several authors suggest that for some students, the ultimate goal is to invest the least amount of effort in learning (Bouffard et al., 1998; Meece \& Holt, 1993). Therefore, these authors propose a three-dimension achievement goals model comprising mastery (approach) goals, performance (approach) goals, and work avoidance goals. This three-dimension model is the one retained for the present study.

\section{Changes in Achievement Motivation across the Transition to Secondary School}

Research has demonstrated that there are significant changes in children's achievement motivation over time (Fredricks \& Eccles, 2002; Watt, 2004; Wigfield et al., 2015). According to a large number of studies, many students appear to become less optimistic over time with respect to their chances of succeeding and show a significant decline in their competence beliefs (Jacobs et al., 2002; Watt, 2004; Wigfield et al., 2006). At the same time, the intrinsic value they assent to different academic domains declines as adolescents increasingly view school as less interesting, significant, and useful (Jacobs et al., 2002). However, it seems that not all children experience the same achievement motivation decline of achievement motivation over time. For example, Archambault, Eccles, and Vida (2010) identified seven different trajectories of student task beliefs (self-concept and task value in literacy) between grade 1 and 12. They showed that most students present a general decline in those beliefs over time, but to different degrees according to their profile. Studies that have examined changes in achievement goals during adolescence are limited. Still, available results do indicate that achievement goals remain mostly stable in elementary school (Meece \& Miller, 2001), while there would be a decrease in mastery goals orientation (Fischer \& Theis, 2014; Paulick, Watermann, \& Nückles, 2013; Shim, Ryan, \& Anderson, 2008) and an increase in avoidance and performance goals during early adolescence (Bouffard, Boileau, \& Vezeau, 2001; Chouinard \& Roy, 2008). This drop in students' self-perceptions, competence beliefs, interest for school and intrinsic motivation has particularly been documented across the transition to secondary school (Benner, 2011; Cantin \& Boivin, 2004; Dotterer, McHale, \& Crouter, 2009; Zanobini \& Usai, 2002).

A variety of explanations have been proposed to explain the decline in motivation after the transition from elementary to secondary school. First, it is tempting to say that the concepts taught in secondary school are more difficult compared to the $6^{\text {th }}$ grade curriculum. Accordingly, these new difficulties may explain the overall decline in student competence 
beliefs and interest. However, there is little evidence to support that assumption (Anderson, et al., 2000). Others state that the phenomenon could be imputed mainly to physiological and psychological changes affecting students at this stage (new interests, enlarged views, lassitude, etc.) (Simmons \& Blyth, 1987). Yet, this claim is not well supported and some authors have pinpointed that many students still encounter difficulties even when their transition occurs in ninth grade instead of seventh grade (Neild, 2008; Smith, 2006).

Other explanations associate the decline in students' motivation to organizational changes occurring between elementary and secondary schools. Some authors suggest that the secondary school environment is more impersonal, competitive, and formal compared to the elementary school setting (Eccles et al. 1993; Coffey, 2013). Secondary schools are larger and more departmentalized, classroom management is more authority-oriented, studentteacher ratios are higher, and lessons are more often given in collective format (Eccles \& Roeser, 2009; Roeser, Urdan, \& Stephens, 2009). As such, it is proposed that the gradual drop in students' motivation during the transition to secondary school could be imputed to the lack of concordance between secondary school organization and the psychological needs of competence, connectedness, and autonomy of adolescents. This explanation is grounded in the stage-environment fit theory (Eccles et al., 1993) which suggests that the secondary school context does not allow teenagers to satisfy the psychological needs corresponding to their stage of development. As a result, using control-oriented discipline and competitive academic values with early adolescents who psychologically seek for more autonomy would tends to produce a mismatch between context and students' developmental needs which, in turn, would be associated with lower levels of motivation (Pianta, 2006). The more formal environment of secondary schools could jeopardize students' connectedness with school, by lowering the quality of the relationships with teachers.

\section{Relationships with teachers}

Effective teachers are expected to be caring, supportive, and emotionally close to each of their students while being responsive to their personal, social, and academic needs (Wentzel, 2015, Coffey, 2013). They also promote democratic and respectful interactions, set expectations for performance based on individual differences, provide constructive feedback and become increasingly critical in the regulation of emotions experienced in the classroom (Pianta, 2006; Wentzel, 2015).Supporting this idea, research shows that students who feel respected and valued by their teachers are more engaged and make more efforts in the classroom (Roorda, Koomen, Spilt, \& Oort, 2011; Wang \& Eccles, 2012). Moreover, perceived warmth and support from teachers have been related to important motivational factors, including mastery goals, interest, utility value, and competence beliefs (Stipek, 2002; Wang \& Holcombe, 2010). The major role on students' achievement motivation is easy to comprehend given the fact that teachers are the first judges of students' skills and that they constantly reflect back to students' judgments on their competence and self-worth, as well as on the utility and value of learning (Patrick, Turner, Meyer, \& Midgley, 2003).

Many authors have emphasized the lower quality of relationships with teachers in secondary school compared to elementary school. For instance, after the transition to secondary school, students would experience a decrease in quantitative and qualitative contact with teachers who trust them less (Eccles \& Roeser, 2009) and with whom their share more conflict (Roderick, 1993). Teachers' classroom management also becomes more controlling, which is in opposition with the increased need of autonomy of adolescents (Eccles \& Roeser, 2009). Because teachers in secondary schools often teach many students per day, the organizational structure of their work does not facilitate the development of close relationships with students and may instead foster feelings of isolation in the latter (Juvonen, 2007). Relationships with teachers thus become more impersonal at a time when adolescents increasingly need the support of adults other than their parents (Pianta, 2006).

Osterman (2000) observed that if, after the transition to secondary school, students feel that they are part of a caring and supportive community, they are likely to display a greater psychological well-being and to preserve beliefs and attitudes that encourage them to engage and persist in learning. In line with these results, Pietarinen, Soini, and Pyhältö (2010) state that when students are not supported adequately by their school, they are more at risk of adopting passive behaviors interfering with their engagement. 


\section{Aim of the present study}

The negative changes observed after the transition to secondary school in students' relationships with teachers and achievement motivation are well documented. However, there is still much work to do before we fully understand whether these changes can be related. Since the declines that occur in students' relationships with teachers and achievement motivation after the transition have mostly been studied separately, the associations between these changes are not well documented (Wang \& Eccles, 2012). In order to address this limitation of previous research, the aim of the present study was to examine how the relationships that girls and boys share with their teachers and how the changes in these relationships are associated with achievement motivation across the transition to secondary school. To attain this goal, we examined the connection between participants' relationships with their teachers and central motivational components: competence beliefs, utility value, interest and achievement goals (mastery, performanceapproach, work avoidance) before the transition and at the beginning and the end of the transition year. Gender was also used as a control variable.

\section{Method}

The present study is based on a sample of French speaking students from the Province of Quebec (Canada). We assessed these students' achievement motivation and the quality of their relationships with teachers using a three-point longitudinal design. This design allowed us to answer our research questions by studying the changes and associations between our different variables at the end of $6^{\text {th }}$ grade (T1), through the beginning (T2) and the end (T3) of Secondary 1. In Quebec schools, $6^{\text {th }}$ grade represents the last year of elementary school in Quebec while Secondary 1 corresponds to the first of the five years of secondary level education. Like elsewhere, there are note worthy differences between primary and secondary schools in the province. To mention the most important one, secondary schools are usually larger and have an extended curriculum. Secondary school students are also generally ascribed to different specialists, in groups averaging 30 students. Conversely, primary school students are ascribed to one generalist teacher for basic subjects and to several specialists for other subjects (arts, second language, physical education, etc.) in classes averaging 25 students.

\section{Participants and Procedure}

At the outset of the study (end of sixth grade), 517 sixth grade students (278 females; mean age 12.18 years, $\sigma=.68$ ) from 17 French public elementary schools were recruited to participate in there search. The following year, 323 of these participants (170 females; mean age at the beginning of the study $=12.83, \sigma=.70$ ) were followed in the public secondary school of their neighborhood (12 schools). Most of the other participants that were lost to the present study transferred to different private secondary schools, which is a common practice in Quebec where public and private institutions are in competition. On average, $20 \%$ of students are educated in the private secondary school system of the province. Nevertheless, results from a multivariate analysis of variance (MANOVA) indicate no significant differences on the dependent variables between the group of participants who left the study after sixth grade and those who were followed after the transition to secondary school $\left(\mathrm{F}_{(9,465)}=.612 ; p=.79\right)$.

\section{Instruments}

Several scales from varied sources were used to collect the data pertaining to the present study. In all cases, participants expressed their opinions on a Likert-type scale ranging from 1 (Totally disagree) to 6 (Totally agree). All scales showed acceptable internal consistency with Cronbach's alphas equal or over .70 (Gliem \& Gliem, 2003).

Competence beliefs, utility value, and interest were measured with adapted scales produced by Ntamakiliro, Monnard, and Gurtner (2000). All three scales comprised four items and assessed academic achievement motivation in general. The competence beliefs scale measured participants' evaluation of their capacity to do well in school (e.g., "I am as capable as others to achieve in school") ( $\alpha=.841)$. Utility value was based on participants' perceptions of present or future usefulness of what they learn and do in class (e.g., "What we learn in school will be useful in my future life") ( $\alpha=.88)$. The interest sub scale assessed the degree to which participants were interested in their classes (e.g. "What we do in school is really interesting") $(\alpha=.78)$. 
Achievement goals (mastery-approach, performance-approach, and work avoidance) were assessed with scales produced and validated by Harackiewicz, Durik, Barron, LinnenbrinkGarcia, and Tauer (2008). All three scales reveal satisfactory levels of reliability and consistency in the French version of the instrument that was used in the present study. The mastery-approach goals subscale $(\alpha=.76)$ entailed three statements assessing the extent to which participants wished to master the content they learn (e.g., "What is really important for me in school is to learn as much as possible."). The performance-approach goals subscale ( $\alpha$ $=.82$ ) consisted of four statements measuring the degree to which participants set as a personal goal to be among the best in their classes and to obtain high marks (e.g., "What is most important for meat school is to achieve better than the other students"). The work avoidance goals subscale $(\alpha=.70)$ was comprised of three statements measuring the degree to which participants set their goals to do the least amount of work possible (e.g., "I always try to work as less as possible in school").

Relationships with teachers were conceptualized based on Adams and Singh (1998) and Wentzel's (1998) definitions which include warmth, support and lack of conflict. From these definitions, we developed and validated a six items scale $(\alpha=.85)$ using exploratory factor analysis. This scale is composed of two items measuring participants' perception of teacher support (e.g., "My teachers make me feel like I can succeed") adapted from the Fennema and Sherman's Mathematics Attitudes Scales (1976). These items were translated in French and validated by Vezeau, Chouinard, Bouffard and Couture (1998). Four other items measuring warmth or lack of conflict in the student-teacher relationships were developed by Janosz, Bouthillier, Bowen, Chouinard and Desbiens (2007) (e.g., "I feel like I am respected by my teachers"; "I often quarrel with my teachers" -this item was reverse coded).

\section{Data Treatment}

Hierarchical Linear Modeling (HLM) was used to model motivational changes according to participants' perception of their relationships with teachers in $6^{\text {th }}$ grade and after the transition to secondary school. HLM techniques are usually used to deal with clustering of students within classrooms or schools. However, in consideration of our research design, where individuals of the same classroom were ascribed to different schools and different classrooms after they were transferred to secondary school, we did not consider the varying hierarchical levels of the data. Instead, as recommended by Woltman, Feldstain, Mackay and Rocchi (2012), we used HLM to account for the heterogeneity of variance that exists across the repeated measures of our research design. As such, HLM analysis technique allowed us to estimate the intercept and the slope for each group and for each variable (Bryk \& Raudenbush, 1992). For clarity and to favor the interpretability of our results, growth models were estimated separately for all achievement motivation outcomes.

Several of the 323 participants that we were able to follow to their secondary school present some missing data. At Times 1 and 2, only a small proportion of missing data was observed (between $1.2 \%$ and $5.3 \%$ ) but at Time 3, that proportion was more important (between 18.9\% and $21 \%$ ). Most students who present missing data were absent from school when data collections were realized at Time 2 and 3. Another main reason for missing data during the same period was the withdrawal from the study of several teachers in the context of union pressure. Data from participants who completed the study to the end $(n=243)$ and those that we were unable to reach at Time $3(n=61)$ were compared at Time 1 and then at Time 2 . Results from our analysis (MANOVA) indicate no significant differences between the two groups on the dependent and independent variables (Time $1: \mathrm{F}_{9,309)}=.663 ; p=.74$; Time 2 : $\left.\mathrm{F}_{(9,294)}=.714 ; p=.70\right)$. As such, we concluded that the data were missing at random (Graham, 2012), which allowed us to impute these missing data in order to make full use of all available information. To do so, we used the missing data multiple imputations procedure of IBM SPSS Statistics (GradPack 21) and computed model parameters from all available data points. This procedure is highly preferable to other popular methods like list wise and pair wise deletion or mean substitution that might bias results (Garson, 2015).

\section{Results}

\section{Preliminary Analysis}

Firstly, we conducted a preliminary analysis with HLM in order to measure general time effect on relationships with teachers between the end of $6^{\text {th }}$ grade and the beginning and the 
end of Secondary 1. Results indicate a general and slight but significant, decrease in relationships with teachers between the end of $6^{\text {th }}$ grade and the beginning of Secondary $1(\beta=$ $-.19, t(322)=-3.67, p<.001)$, and a much more considerable decrease between $6^{\text {th }}$ grade and the end of Secondary $1(\beta=-.57, t(322)=-9.94, p<.001)$.

\section{BaselineModel}

Secondly, in order to document exclusively the evolution of motivation after the transition to secondary school, we measured time effect on each dependent variable ( $Y$ ) with a baseline model with no interaction variables at level 2. In this model (see equation below), $\mathrm{P}_{1}$ represents the dependent variables at $\mathrm{T} 1, \mathrm{P}_{2}$ the slope between time 1 and time 2 , and $\mathrm{P}_{3}$ the slope between $\mathrm{T} 1$ and $\mathrm{T} 3$. The resulting regression equation is:

Level-1

$Y=P_{1}+P_{2}(T 2)+P_{3}(T 3)+E$

Level-2

$\mathrm{P}_{1}=\mathrm{B}_{00}$

$\mathrm{P}_{2}=\mathrm{B}_{10}+\mathrm{R}_{1}$

$\mathrm{P}_{3}=\mathrm{B}_{20}+\mathrm{R}_{2}$

As reported in Table 1 and 2, interest, mastery goals and work avoidance showed significant changes between the end of $6^{\text {th }}$ grade and the two times of measurement in Secondary 1; these changes are negative in the case of interest (-.12 and -.32) and mastery goals (-.12 and $.34)$ and positive in the case of work avoidance (.09 and .34). For all these variables, the magnitude of the changes observed is larger between T1 and T3 than between T1 and T2. Students' competence beliefs and utility value also showed a decline over time, but this decline was significant only by the end of Secondary 1 (-.26 and -.21 , respectively). Finally, performance-approach goals reflected no significant time effect.

Table 1. Parameter Estimate (standard errors) and Significant Test for Time-Only Model on Expectancy-Value Variables

\begin{tabular}{|c|c|c|c|c|c|c|c|}
\hline & & \multicolumn{2}{|c|}{ Competence Beliefs } & \multicolumn{2}{|c|}{$\underline{\text { Utility Value }}$} & \multicolumn{2}{|c|}{ Interest } \\
\hline & & $\beta$ (err.) & $\underline{t \text {-value }}$ & $\beta$ (err.) & $\underline{\mathrm{t} \text {-value }}$ & $\beta$ (err.) & $\underline{\mathrm{t} \text {-value }}$ \\
\hline T1 & & $4.69(.06)$ & $78.07^{\star}$ & $5.38(.05)$ & $115.24^{*}$ & $4.34(.06)$ & $74.62^{*}$ \\
\hline T2 & Slope & $.04(.05)$ & .85 & $-.02(.04)$ & -.47 & $-.12(.06)$ & $-2.28^{*}$ \\
\hline T3 & Slope & $-.26(.06)$ & $-4.50^{*}$ & $-.21(.05)$ & $-3.99^{*}$ & $-.32(.06)$ & $-5.28^{*}$ \\
\hline
\end{tabular}

Degrees of freedom for level 1 variable $=966$ and $=322$ for level 2 variables.

${ }^{*} p<.05$

Table 2. Parameter Estimate (standard errors) and Significant Test for Time-Only Model on Achievement Goals Variables

\begin{tabular}{ccccccccc}
\hline & \multicolumn{2}{c}{ Mastery-Approach } & & \multicolumn{2}{c}{ Performance-Approach } & & \multicolumn{2}{c}{ WorkAvoidance } \\
& & $\underline{\beta(\text { err. })}$ & $\underline{\mathrm{t} \text {-value }}$ & $\underline{\beta(\mathrm{err})}$ & $\underline{\mathrm{t} \text {-value }}$ & $\underline{\beta(\mathrm{err})}$ & $\underline{\underline{\mathrm{t} \text {-value }}}$ \\
$\mathrm{T} 1$ & & $5.43(.04)$ & $132.48^{*}$ & $3.38(.07)$ & $49.36^{*}$ & $1.71(.05)$ & $33.75^{*}$ \\
T2 & Slope & $-.12(.04)$ & $-2.93^{*}$ & $-.05(.06)$ & -.78 & $.09(.05)$ & $2.03^{*}$ \\
T3 & Slope & $-.34(.05)$ & $-6.19^{*}$ & $-.10(.07)$ & -1.43 & $.34(.06)$ & $6.11^{*}$ \\
\hline
\end{tabular}

Degrees of freedom for level 1 variable $=966$ and $=322$ for level 2 variables .

${ }^{*} p<.05$

\section{Interest}

At the end of $6^{\text {th }}$ grade, participants with better relationships with teachers also reported greater interest in academic tasks (.60). Analyses also indicate that interest significantly 
varied with the fluctuation of the relationships with teachers in T2 and T3 (.49 and .43 respectively).

\section{Final Model}

In order to document the moderating effect of gender and relationships with teachers, our final model encompassed four predictive variables: gender, relationships with teachers (RT) at the end of $6^{\text {th }}$ grade (T1), the difference between RT at the beginning of Secondary 1 (T2) and the end of $6^{\text {th }}$ grade $\left(\Delta R T_{\text {T2-T1 }}\right)$, as well as the difference between $R T$ at the end of Secondary 1 (T3) and the end of 6th grade $\left(\Delta R T_{\text {T3-T1 }}\right)$. The changes in the relationships with teachers, for example $\mathrm{RT}_{\mathrm{T} 2-\mathrm{T} 1}$, were calculated by computing the difference between participants score between times (here, score at T2 minus score at T1). As such, a positive value can be interpreted as an improvement of the relationships over time and a negative value as deterioration. The resulting regression equation is:

Level 1

$Y=P_{1}+P_{2}(T 2)+P_{3}(T 3)+E$

Level-2

(1)

$\mathrm{P}_{1}=\mathrm{B}_{00}+\mathrm{B}_{01}($ Gender $)+\mathrm{B}_{02}\left(\mathrm{RT}_{\mathrm{T} 1}\right)$

(2)

$\mathrm{P}_{2}=\mathrm{B}_{10}+\mathrm{B}_{11}($ Gender $)+\mathrm{B}_{12}\left(\Delta \mathrm{RT}_{\mathrm{T} 2-\mathrm{T} 1}\right)+\mathrm{R}_{1}$

(3)

$\mathrm{P}_{3}=\mathrm{B}_{20}+\mathrm{B}_{21}($ Gender $)+\mathrm{B}_{22}\left(\Delta \mathrm{RT}_{\mathrm{T} 3-\mathrm{T} 1}\right)+\mathrm{R}_{2}$

In this equation, $Y$ corresponds to the dependent motivational variable and $P_{1}$ is the initial state of the dependent variable at the end of $6^{\text {th }}$ grade, moderated by RT at T1. $\mathrm{P}_{2}$ and P3relaterespectively to the slope between T1 and T2 and between T1 and T3. However, contrary to the baseline model, these last slopes are moderated by gender and changes of $\mathrm{RT}\left(\Delta \mathrm{RT} \mathrm{T}_{\mathrm{T} 2 \mathrm{~T} 1}\right.$ for $\mathrm{P}_{2}$ and $\Delta R \mathrm{~T}_{\mathrm{T} 3-\mathrm{T} 1}$ for $\left.\mathrm{P}_{3}\right)$.

\section{Competence Beliefs}

As illustrated in Table 3, by the end of $6^{\text {th }}$ grade, participants reporting better relationships with teachers also reported higher competence beliefs (.33). Results further show that participants' scores on competence beliefs in T2 and T3 varied significantly with the changes in their relationships with teachers, positively if these relationships improved and negatively if they deteriorated (T2 slope $=.26$; T3 slope $=.28$ ).

\section{Utility Value}

Participants who reported better relationships with teachers at the end of $6^{\text {th }}$ grade also reported higher utility value at the same time (.25). Additionally, results indicate that the changes in utility value significantly fluctuated with the variations of participants' relationships with their teachers in T2 and T3. For example, participants who reported anamelio ration of their relationships also reported a lesser decline or no decline at all of utility value (T2 slope = .24 and T3 slope $=.29$ ). 
Table 3. Parameter Estimate (standard errors) and Significant Test for Final Model on Expectancy-Value Variables

\begin{tabular}{|c|c|c|c|c|c|c|c|}
\hline & & \multicolumn{2}{|c|}{ Competence Beliefs } & \multicolumn{2}{|c|}{ Utility Value } & \multicolumn{2}{|c|}{$\underline{\text { Interest }}$} \\
\hline & & $\beta$ (err.) & $\underline{\mathrm{t} \text {-value }}$ & $\beta$ (err.) & t-value & $\beta$ (err.) & $\underline{\mathrm{t} \text {-value }}$ \\
\hline \multirow[t]{3}{*}{ T1 } & & $4.70(.09)$ & $53.88^{*}$ & $5.29(.07)$ & $73.94^{*}$ & $4.24(.08)$ & $54.61^{*}$ \\
\hline & Gender & $-.01(.12)$ & -0.05 & $.17(.09)$ & 1.87 & .19 & 1.81 \\
\hline & $\mathrm{RT}_{\mathrm{T} 1}$ & $.33(.07)$ & $4.76^{*}$ & $.26(.05)$ & $4.91^{*}$ & .60 & $11.55^{*}$ \\
\hline \multirow[t]{3}{*}{ T2 } & Slope & $.10(.08)$ & 1.19 & $.11(.07)$ & 1.52 & $.02(.08)$ & .27 \\
\hline & Gender & $-.01(.10)$ & -0.09 & $-.15(.09)$ & -1.77 & $-.10(.10)$ & -1.00 \\
\hline & $\Delta \mathrm{RT}_{\mathrm{T} 2}-\mathrm{T} 1$ & $.26(.06)$ & $4.10^{*}$ & $.24(.04)$ & $5.63^{*}$ & $.49(.06)$ & $8.09^{*}$ \\
\hline \multirow[t]{3}{*}{ T3 } & Slope & $.00(.09)$ & -0.04 & $.04(.08)$ & .50 & $.03(.09)$ & .37 \\
\hline & Gender & $-.18(.11)$ & -1.58 & $-.15(.10)$ & -1.52 & $-.20(.11)$ & -1.86 \\
\hline & $\Delta \mathrm{RT}_{\mathrm{T} 3-\mathrm{T} 1}$ & $.28(.06)$ & $4.53^{*}$ & $.29(.05)$ & $5.43^{*}$ & $.43(.05)$ & $8.05^{*}$ \\
\hline
\end{tabular}

$\mathrm{RT}=$ Relationships with teachers

Degrees of freedom for Level 1 variables $=960$

Degrees of freedom for Level 2 variables $=320$

Males $=0$, Females $=1$

${ }^{*} p<.05$

\section{Mastery-Approach Goals}

As shown in Table 4, participants who reported better relationships with teachers by the end of 6 th grade also reported higher mastery goals at the same period (.33). Moreover, analyses show that mastery-approach goals significantly evolved overtime in relation with the changes reported on students' relationships with their teachers(.34 and .35 respectively).

Table 4. Parameters Estimate (standard errors) and Significant Test for Final Model on Achievement Goals Variables

\begin{tabular}{|c|c|c|c|c|c|c|c|}
\hline & & \multicolumn{2}{|c|}{ Mastery-Approach } & \multicolumn{2}{|c|}{ Performance-Approach } & \multicolumn{2}{|c|}{$\underline{\text { Work-Avoidance }}$} \\
\hline & & $\beta$ (err.) & $\underline{\mathrm{t} \text {-value }}$ & $\beta$ (err.) & $\underline{\mathrm{t} \text {-value }}$ & $\beta$ (err.) & $\underline{\mathrm{t} \text {-value }}$ \\
\hline & & $5.38(.06)$ & 91.19* & $3.66(.10)$ & $34.95 *$ & $1.80(.07)$ & $25.26 *$ \\
\hline \multirow[t]{2}{*}{$\mathrm{T} 1$} & Gender & $.09(.08)$ & 1.13 & $-.52(.14)$ & $-3.75^{*}$ & $-.17(.09)$ & -1.86 \\
\hline & $\mathrm{RT}_{\mathrm{T} 1}$ & $.33(.04)$ & $7.44^{*}$ & $.16(.07)$ & $2.38^{*}$ & $-.38(.05)$ & $-7.56 *$ \\
\hline \multirow[t]{3}{*}{$\mathrm{T} 2$} & Slope & $-.01(.06)$ & -.20 & $-.13(.10)$ & -1.28 & $-.02(.07)$ & -.41 \\
\hline & Gender & $-.09(.08)$ & -1.14 & $.22(.13)$ & 1.74 & $.15(.09)$ & 1.65 \\
\hline & $\Delta \mathrm{RT}_{\mathrm{T} 2-\mathrm{T} 1}$ & $.34(.05)$ & $6.76^{*}$ & $.18(.06)$ & $2.92^{*}$ & $-.23(.05)$ & $-4.11 *$ \\
\hline \multirow[t]{3}{*}{ T3 } & Slope & $-.09(.08)$ & -1.11 & $-.05(11)$ & -.46 & $.16(.08)$ & $2.02 *$ \\
\hline & Gender & $-.10(.10)$ & -.94 & $.14(.14)$ & 1.01 & $.06(.11)$ & .52 \\
\hline & $\Delta \mathrm{RT}_{\mathrm{T} 3-\mathrm{T} 1}$ & $.35(.05)$ & $7.14^{*}$ & $.21(.06)$ & $3.84 *$ & $-.26(.06)$ & $-4.39 *$ \\
\hline
\end{tabular}

$\mathrm{RT}=$ Relationships with teachers

Degrees of freedom for Level 1 variables $=960$

Degrees of freedom for Level 2 variables $=320$

Males $=0$, Females $=1$

${ }^{*} p<.05$ 


\section{Performance-Approach Goals}

Participants who reported better relationships with teachers by the end of $6^{\text {th }}$ grade also reported higher performance-approachgoals at the same period (.16). Overtime, a significant effect of relationships was found (.18 and .21), indicating that students' performanceapproach goals were related with the changes in their relationships with teachers.

\section{Work Avoidance Goals}

By the end of $6^{\text {th }}$ grade, participants with better relationships with teachers reported lower work avoidance goals (-.38). After the transition to secondary school (T2 and T3), work avoidance goals significantly increased (see Table 2), but those changes were moderated by student-teacher relationships adjustments. Thus, for participants reporting an improvement or a decline of their relationships with teachers between Time 1 and Time 2 as well as between Time 1 and Time 3, we observed reversed changes of work avoidance goals (-.23 and -.26, respectively).

Finally, males (coded 0 ) and females (coded 1) reported similar results on all dependent variables at the outset of the study, except for performance-approach goals on which males significantly scored higher than females. Otherwise, no significant moderating gender effect was observed at T2 and T3, meaning that females and males reported equivalent changes on the dependent variables across time with no gender-time interaction.

\section{Discussion and Conclusion}

The aim of this two-year longitudinal study was to examine how relationships with teachers are associated with girls' and boys' achievement motivation before and after the transition to secondary school. This research is the first that addressed how changes in teacher-student relationships are associated with the changes on students' expectation of success, value, and achievement goals at different points in time, from the end of 6th grade, through the beginning and the end of Secondary 1. Based on previous research, we put forth the hypothesis that students who experience an improvement of the relationships they share with teachers following the transition to secondary school will present a lower decline of their achievement motivation. Overall, our results support this idea; positive changes in students' relationships with teachers across the transition were associated with lower decrease in students' achievement motivation.

Results first indicate that relationships with teacher sand achievement motivation co-varied before and after the transition to secondary school and that these variables generally declined following the transition. These findings concur with those of other researchers who have posited that students tend to reevaluate their academic expectancy, value and goals after the transition to secondary school (Bouffard et al., 2001; Fischer \& Theis, 2014; Paulick et al., 2013; Shim et al., 2008).

Our results further indicate that students who improved the quality of the relationships with their teachers right after the transition to secondary school and through the end of the transition year tended to present a lesser decline of their academic achievement goals, expectancies and values while the invert tendency was observed for those who experienced a deterioration of their relationships with teachers. Although it is the first time that research assesses how changes in students' relationships with teachers influence changes in their achievement motivation, this finding is in line with previous work showing that the quality of the relationships with teachers epresents a very important predictor of students' motivation in school (Grolnick et al., 2002; Opdenakker, Maulana, \& den Brok, 2012; Pianta, Hamre, \& Allen, 2012; Wentzel, 2015).Through their interactions with students, teachers send them important messages about their self-worth as well as about the value and significance of learning (Patrick et al., 2003; Wentzel, 2014). In doing so, they continuously lead students to reevaluate their skills and goals, and when the relationships with the students are harmonious, the messages that teachers give them seem to contribute to their motivation to achieve. In our own results, scores on motivational variables were significantly higher for students' who reported an improvement of the relationships with teachers than for their counterparts who experienced a decrease in these relationships. Such results support the hypothesis that changes in the relationships with teachers during the transition can act as a risk or a protective factor, depending on the student's perception of the quality of these relationships. 
That being said, the overall deterioration of students' relationships with teachers and achievement motivation also supports the stage-environment fit theory that posits that secondary school might not properly meet the relational needs of young adolescents and, therefore, might be less beneficial than elementary school for student achievement motivation (Eccles et al., 1993). These findings highlight the link between relationships with teachers and achievement motivation underlined by other researchers (Faircloth \& Hamm, 2005; Ibañez, Kuperminc, Jurkovic, \& Perilla, 2004; McMahon, Wernsman, \& Rose, 2009; Nelson \& DeBacker, 2008). That also coincide with the observation that positive connectedness with teachers could be a factor favoring a smooth transition and may eventually be an indicator of the quality of the adaptation after this transition (Akos, 2006; Akos \& Galassi, 2004).

The methodological limitations of the present investigation include the following concerns. Firstly, the analyses used in the treatment of the data are correlational in nature, and thus, causal relations cannot be inferred. Secondly, because we used a convenience sample and we lost the participants who transferred to private secondary schools after 6th grade, our results may only apply to public secondary school students, which limits the generalizability of our findings. As such, in future work, it would be interesting to include a sub sample of students from private schools. Finally, the methodological approach model used focused on a quantitative design only. A mixed approach model including observations or interviews of students would better adjust with the aim of the study.

In conclusion, many researchers have criticized secondary school for not doing enough to help students experiment positive relationships with teachers, which would contribute to the satisfaction of their connectedness needs (Certo, Cauley, \& Chafin, 2003; Newman Kingery, Erdley, \& Marshall, 2011; Osterman, 2000). Nevertheless, few studies have examined the link between achievement motivation and the quality of student-teacher relationships in the context of the transition to secondary school. The results of the present study indicate that the quality of the changes in students' relationships with teachers is linked to the changes in achievement motivation at the outset of secondary education. In our opinion, this challenges the actual organization of secondary school environments and advocate for adjustments to make them more suitable to the connectedness need of adolescents.

\section{Notes}

1. All internal consistency measures come from the sample of the present study.

2. At the beginning of Secondary 1 , we observed that $48 \%$ of the participants reported a deterioration of the relationships with their teachers, $37 \%$ stated an improvement and $15 \%$ reported no change at all. Between the end of 6 th grade and the end of Secondary 1 , $66 \%$ of them reported a decline, $23 \%$ an improvement and $11 \%$ reported no change in their relationships with teachers.

\section{Acknowledgement}

This work was supported by the Fonds de recherche du Québec and Ministère de l'Éducation et de l'enseignement supérieur du Québec through the program Réussite et persévérance scolaire. Grant no: R0019096.

The authors would like to thank the principals, teachers, students, and parents of the cooperating schools for their participation. 


\section{References}

Adams, R.C., \& Singh, K. (1998). Direct and indirect effects of school learning variables on the academic achievement of African American $10^{\text {th }}$ graders. The Journal of Negro Education.67(1), 48-66.doi: $10.2307 / 2668240$

Akos, P. (2006). Extracurricular participation and the transition to middle school. RMLE Online: Research in Middle Level Education, 29(9), 1-9. doi: 10.1080/19404476.2006.11462032

Akos, P., \& Galassi, J. P. (2004). Gender and race as variables in psychosocial adjustment to middle and high school. The Journal of Educational Research, 98(2), 102-108. doi: 10.3200/JOER.98.2.102108

Ames, C. 1992. Classrooms: Goals, structures, and student motivation. Journal of Educational Psychology, 84, 261-271.doi:10.1037/0022-0663.84.3.261

Anderson, L. W., Jacobs, J, Schramm, S,Splittgerber, F. (2000). School transitions: Beginning of the end or a new beginning? International Journal of Educational Research, 33, 325-339.

Archambault, I., Eccles, J. S., \& Vida, M. N. (2010). Ability self-concepts and subjective value in literacy: Joint trajectories from grade 1 through 2. Journal of Educational Psychology, 102(4), 804-816. doi: 10.1037/a0021075

Bandura, A. (1997). Self-efficacy: The Exercise of Control. New York: Freeman.

Benner, A. D. (2011). The transition to high school: Current knowledge, future directions. Educational Psychology Review, 23(3), 299-328. doi: 10.1007/s10648-011-9152-0

Benner, A. D., \& Graham, S. (2009). The transition to high school as a developmental process among multi-ethnic urban youth. Child Development, 80(2), 356-376. doi: 10.1111/j.1467-8624.2009.01265.x

Bouffard, T., Boileau, L., \& Vezeau, C. (2001). Students' transition from elementary to high school and changes of the relationship between motivation and academic performance. European Journal of Psychology of Education, 16(4), 589-604. doi: 10.1007/BF03173199

Bouffard, T., Boisvert, J., Vezeau, C., \& Larouche, C. (1995). The impact of goal orientation of selfregulation and performance among college students. British Journal of Educational Psychology, 65(3), 317-329. doi: 10.1111/j.2044-8279.1995.tb01152.x

Bouffard, T., Vezeau, C., Romano, G., Chouinard, R., Bordeleau, L., \& Filion, C. (1998). Élaboration et validation d'un instrument pour évaluer les buts des élèves en contexte scolaire. Canadian Journal of Behavioural Science/Revue canadienne des sciences du comportement, 30(3), 203-206. doi: 10.1037/h0087063

Bryk, A. S., \& Raudenbush, S. (1992). Hierarchial linear models. Newbury Park, CA: Sage Publications.

Cantin, S., \& Boivin, M. (2004). Change and stability in children's social network and self-perceptions during transition from elementary to junior high school. International Journal of Behavioral Development, 28(6), 561-570. doi: 10.1080/01650250444000289

Certo, J. L., Cauley, K. M., \& Chafin, C. (2003). Students' perspectives on their high school experience. Adolescence, 38(152), 705-724.

Chouinard, R., \& Roy, N. (2008). Changes in high-school students' competence beliefs, utility value, and achievement goals in mathematics. British Journal of Educational Psychology, 78(1), 31-50. doi: 10.1348/000709907X197993

Coffey, A. (2013). Relationships: The key to successful transition from primary to secondary school? Improving Schools, 16(3), 261-271. doi: 10.1177/1365480213505181

Dotterer, A. M., McHale, S. M., \& Crouter, A. C. (2009). The development and correlates of academic interests from childhood through adolescence. Journal of Educational Psychology, 101(2), 509-519. doi: $10.1037 / a 0013987$

Duchesne, S., Ratelle, C. F., \& Feng, B. (2014). Developmental trajectories of achievement goal orientations during the middle school transition: The contribution of emotional and behavioral dispositions. The Journal of Early Adolescence, 34(4), 486-517. doi: 10.1177/0272431613495447

Dweck, C. S. (1992). The study of goals in psychology. Psychological Science, 3(3), 165-167. doi: 10.1111/j.1467-9280.1992.tb00019.x

Eccles, J. S., \& Roeser, R. (2009). Schools, academic motivation, and stage-environment fit. In R.Lerner \& L.Steinberg (Eds.), Handbook of adolescent psychology ( $3^{\text {rd }}$ ed.) (pp. 404-434). Hoboken, 
NJ: John Wiley\& sons.

Eccles, J. S., \& Wigfield, A. (2002). Motivational beliefs, values, and goals. Annual Review of Psychology, 53,109-132. doi: 10.1146/annurev.psych.53.100901.135153

Eccles, J. S., Wigfield, A., Midgley, C., Reuman, D., Mac Iver, D., \& Feldlaufer, H. (1993). Negative effects of traditional middle schools on students' motivation. The Elementary School Journal. 93(5), 553-574.doi: 10.1086/461740

Elliot, A. J., Murayama, K., \& Pekrun, R. (2011). A $3 \times 2$ achievement goal model. Journal of Educational Psychology, 103(3), 632-648. doi: 10.1037/a0023952

Faircloth, B. S., \& Hamm. J. V. (2005). Sense of belonging among high school students representing 4 ethnic groups. Journal of Youth and Adolescence, 34(4), 293-309. doi: 10.1007/s10964-005-5752-7

Fennema, E., \& Sherman, J. A. (1976). Fennema-Sherman mathematics attitudes scales: Instruments designed to measure attitudes toward the learning of mathematics by females and males. Journal of Research in Mathematics Education, 7(5), 324-326. doi: 10.2307/748467

Fischer, N., \& Theis, D. (2014). Extracurricular participation and the development of school attachment and learning goal orientation: The impact of school quality. Developmental Psychology, 50(6), 1788-1793. doi: 10.1037/a0036705

Fredricks, J. A., \& Eccles, J. S. (2002). Children's competence and value beliefs from childhood through adolescence: Growth trajectories in two male-sex-typed domains. Developmental Psychology, 38(4), 519-533. doi: 10.1037/0012-1649.38.4.519

Garson, G. D. (2015). Missing values analysis and data imputation. Asheboro, NC: Statistical Publishing Associates.

Gehlbach, H., Brinkworth, M. E., \& Harris, A. D. (2012). Changes in teacher-student relationships. British Journal of Educational Psychology, 82(4), 690-704. doi: 10.1111/j.2044-8279.2011.02058.x

Gliem, J. A., \& Gliem, R. R. (2003). Calculating, interpreting, and reporting Cronbach's alpha reliability coefficient for Likert - type scales. Midwest Research to Practice Conference in Adult, Continuing, and Community Education, retrieved April23, 2014 from http://www.alumni-osu.org/ midwest/midwest \%20 papers/Gliem\%20\&\%20Gliem--Done.pdf.

Gottfried, A. E., Fleming, J. S., \& Gottfried, A. W. (2001). Continuity of academic intrinsic motivation from childhood through late adolescence: A longitudinal study. Journal of Educational Psychology, 93(1), 3-13. doi: 10.1037/0022-0663.93.1.3

Graham, J. W. (2012).Missing data: Analysis and design. New York, NY: Springer.

Grills-Taquechel, A. E., Norton, P., \& Ollendick, T. H. (2010). A longitudinal examination of factors predicting anxiety during the transition to middle school. Anxiety, Stress, \& Coping, 23(5), 493-513. doi: $10.1080 / 10615800903494127$

Grolnick, W. S., Gurland, S. T., DeCourcey, W., \& Jacob, K. (2002). Antecedents and consequences of mothers' autonomy support: An experimental investigation. Developmental Psychology, 38(1), 143-155. doi: 10.1037/0012-1649.38.1.143

Harackiewicz, J. M., Barron, K. E., Pintrich, P. R., Elliot, A. J., \& Thrash, T. M. (2002). Revision of achievement goal theory: Necessary and illuminating. Journal of Educational Psychology, 94(3), 638-645. doi: 10.1037/0022-0663.94.3.638

Harackiewicz, J. M., Durik, A. M., Barron, K. E., Linnenbrink-Garcia, L., \& Tauer, J. M. (2008). The role of achievement goals in the development of interest: Reciprocal relations between achievement goals, interest, and performance. Journal of Educational Psychology, 100(1), 105-122. doi: 10.1037/00220663.100.1.105

Hardré, P. L. (2015). Seeing the big picture: A systemic perspective on motivation. In C. M. RubieDavies, J. M. Stephens \& P. Watson (Eds.), The Routledge International Handbook of Social Psychology of the Classroom (pp.21-30). New York, NY: Routledge.

Ibañez, G. E., Kuperminc, G. P., Jurkovic, G., \& Perilla, J. (2004). Cultural attributes and adaptations linked to achievement motivation among Latino adolescents. Journal of Youth and Adolescence, 33(6), 559-568. doi: 10.1023/B:JOYO.0000048069.22681.2c

Jacobs, J. E., Lanza, S., Osgood, D. W., Eccles, J. S., \& Wigfield, A. (2002). Changes in children's selfcompetence and values: Gender and domain differences across grades one through twelve. Child Development, 73(2), 509-527. doi: 10.1111/1467-8624.00421

Janosz, M., Bouthillier, C., Bowen, F, Chouinard, R., \& Desbiens, N. (2007). Rapport de validation du 
Questionnaire sur l'environnement socioéducatif des écoles primaires (QES-primaire). Montréal, Québec: Université de Montréal.

Jozsa, K., \& Morgan, G. A. (2014). Developmental changes in cognitive persistence and academic achievement between grade 4 and grade 8. European Journal of Psychology of Education, 29(3), 521-535. doi: 10.1007/s10212-014-0211-z

Juvonen, J. (2007). Reforming middle schools: Focus on continuity, social connectedness, and engagement. Educational Psychologist, 42(4), 197-208. doi: 10.1080/00461520701621046

McMahon, S. D., Wernsman, J., \& Rose, D. S. (2009). The relation of classroom environment and school belonging to academic self-efficacy among urban fourth- and fifth-grade students. Elementary School Journal, 109(3), 267-281. doi: 10.1086/592307

Meece, J. L., \& Holt, K. (1993). A pattern analysis of students' achievement goals. Journal of Educational Psychology, 85(4), 582-590. doi: 10.1037/0022-0663.85.4.582

Meece, J. L., \& Miller, S. D. (2001). A longitudinal analysis of elementary school students' achievement goals in literacy activities. Contemporary Educational Psychology, 26(4), 454-480. doi: 10.1006 /ceps.2000.1071

Neild, R. C. (2009). Falling off track during the transition to high school: What we know and what can be done. The Future of Children, 19(1), 53-76. doi: 10.1353/foc.0.0020

Nelson, R. M., \& DeBacker, T. K. (2008). Achievement motivation in adolescents: The role of peer climate and best friends. The Journal of Experimental Education, 76(2), 170-189. doi: 10.3200 IJEXE.76.2.170-190

Newman Kingery, J., Erdley, C. A., \& Marshall, K. C. (2011). Peer acceptance and friendship as predictors of early adolescents' adjustment across the middle school transition. Merrill-Palmer Quarterly, 57(3), 215-243. doi: 10.1353/mpq.2011.0012

Nicholls, J. G. (1984). Achievement motivation: Conceptions of ability, subjective experience, task choice, and performance. Psychological Review, 91(3), 328-346. doi: 10.1037/0033-295X.91.3.328

Ntamakiliro, L., Monnard, I., \& Gurtner, J. L. (2000). Mesure de la motivation scolaire des adolescents: construction et validation de trois échelles comportementales. L'orientation scolaire et professionnelle, 29(4), 673-693.

Opdenakker, M. C., Maulana, R., \& den Brok, P. (2012). Teacher-student interpersonal relationships and academic motivation within one school year: Developmental changes and linkage. School Effectiveness and School Improvement, 23(1), 95-119. doi: 10.1080/09243453.2011.619198

Osterman, K. F. (2000). Students' need for belonging in the school community. Review of Educational Research, 70(3), 323-367. doi: 10.3102/00346543070003323

Patrick, H., Turner, J.C., Meyer, D.K., \& Midgley, C. (2003). How teachers establish psychological environments during the first days of school: Associations with avoidance in mathematics. Teachers College Record, 105(8), 1521-1558. doi:10.1111/1467-9620.00299

Paulick, I., Watermann, R., \& Nückles, M. (2013). Achievement goals and school achievement: The transition to different school tracks in secondary school. Contemporary Educational Psychology, 38(1), 75-86. doi: 10.1016/j.cedpsych.2012.10.003

Pianta, R. C. (2006). Classroom management and relationships between children and teachers: Implications for research and practice. In C. M. Evertson \& C. S. Weinstein (Eds), Handbook of Classroom Management (pp. 685-709). Mahwah, NJ: Lawrence Erlbaum Associates.

Pianta, R. C., Hamre, B. K., \& Allen, J. P. (2012). Teacher-student relationships and engagement: Conceptualizing, measuring, and improving the capacity of classroom interactions. In S. L. Christenson, A. L. Reschly \& C. Wylie (Eds.), Handbook of research on student engagement (365-386). New York, NY: Springer.

Pietarinen, J., Soini, T. et Pyhältö, K. (2010). Learning and well-being in transitions: How to promote pupils' active learning agency? In D. Jindal-Snape (Ed.), Educational transitions: Moving stories from around the world (pp. 143-158). New York, NY: Routledge.

Ratelle, C., Guay, F., Larose, S., \& Senécal, C. (2004). Family correlates of trajectories of academic motivation during a school transition: A semi parametric group-based approach. Journal of Educational Psychology 96(4): 743-754. doi: 10.1037/0022-0663.96.4.743

Roderick, M. (1993). The path to dropping out: Evidence for intervention. Westport, CT: Auburn House.

Roeser, R. W., Urdan, T. C., \& Stephens, J.M. (2009). School as a context of student motivation and 
achievement. In K. R. Wentzel \& A. Wigfield (Eds.), Handbook of motivation at school (pp. 381-410). NewYork, NY: Routledge.

Roorda, D. L., Koomen, H. M. Y., Spilt, J. L., \& Oort, F. J. (2011). The influence of affective teacherstudent relationships on students' school engagement and achievement: A meta-analytic Approach. Review of Educational research, 81(4), 493-529. doi: 10.3102/0034654311421793

Shim, S. S., Ryan, A. M., \& Anderson, C. J. (2008). Achievement goals and achievement during early adolescence: Examining time-varying predictor and outcome variables in growth-curve analysis. Journal of Educational Psychology, 100(3), 655-671. doi: 10.1037/0022-0663.100.3.655

Simmons, R. G., \& Blyth, D. A. (1987). Moving into adolescence: The impact of pubertal change and school context. Hawthorne, NY: Aldine de Gruyter.

Smith, J. S. (2006). Examining the long-term impact of achievement loss during the transition to high school. Journal of Advanced Academics, 17(4), 211-221. doi: 10.4219/jsge-2006-409

Stipek, D. J. (2002). Good instruction is motivating. In A. Wigfield \& J. Eccles (Eds.), Development of achievement motivation (pp. 27-46). San Diego, CA: Academic Press.

Tonkin, S. E., \& Watt, H. M. G. (2003). Self-concept over the transition from primary to secondary school: A case study on a program for girls. Issues in Educational Research, 13(2), 27-54.

Vezeau, C., Chouinard, R., Bouffard, T., \& Couture, N. (1998). Adaptation et validation des échelles de Fennema-Sherman sur les attitudes en mathématiques chez des garçons et des filles du secondaire. Revue canadienne des sciences du comportement, 30(2), 137-140. doi: 10.1037/h0085804

Wang, M. T., \& Eccles, J. S. (2012). Social support matters: Longitudinal effects of social support on three dimensions of school engagement from middle to high school. Child Development, 83(3), 877-895. doi: 10.1111/j.1467-8624.2012.01745.x

Wang, M. T., \& Holcombe, R. (2010). Adolescents' perceptions of school environment, engagement, and academic achievement in middle school. American Educational Research Journal, 47(3), 633-662. doi: 10.3102/0002831209361209

Watt, H. M. G. (2004). Development of adolescents' self-perceptions, values, and task perceptions according to gender and domain in 7th through 11th-grade Australian students. Child Development, 75(5), 1556-1574. doi: 10.1111/j.1467-8624.2004.00757.x

Wentzel, K. (2010). Students' relationships with teachers. In J. Eccles \& R. Roeser (Eds.) Handbook of research on schools, schooling and human development (75-91). New York, NY: Routledge.

Wentzel, K. R. (1998). Social relationships and motivation in middle school: The role of parents, teachers, and peers. Journal of Educational Psychology, 90(2), 202-209. doi: 10.1037/00220663.90.2.202

Wentzel, K. R. (2002). Are effective teachers like good parents? Teaching styles and student adjustment in early adolescence. Child Development, 73(1), 287-301. doi: 10.1111/1467-8624.00406

Wentzel, K.R. (2014). Socialization in school settings. In J. E. Grusec and P. D. Hastings (Eds.) Handbook of socialization: Theory and research (Vol. 2, pp. 251-275). New York, NY: Guilford Press.

Wentzel, K. R. (2015). Teacher-student relationships, motivation, and competence at school. In C. M. Rubie-Davies, J. M. Stephens \& P. Watson (Eds.), The Routledge international handbook of social psychology of the classroom (pp. 167-176). New York, NY: Routledge.

Wigfield, A., Cambria, J., \& Eccles, J. S. (2012). Motivation in education. In R. M. Ryan (Ed.), The Oxford handbook of human motivation (pp. 463-478). New York, NY: Oxford University Press.

Wigfield, A, Eccles, J. S., Fredricks, J., Simpkins, Roeser R., \& Schiefele, U. (2015). Development of achievement motivation and engagement. In R. Lerner (Series ed.), M. Lamb, \& C. Garcia Coll (Vol. Eds.), Handbook of child psychology and developmental science (7th ed., Vol. 3, pp. 657-700). New York, NY: Wiley.doi: 10.1002/9781118963418

Wigfield, A., Eccles, J. S., Schiefele, U., Roeser, R., \& Davis-Kean, P. (2006). Development of achievement motivation. InW. Damon (Series Ed.) \& N. Eisenberg (Volume Ed.), Handbook of child psychology: Social, emotional, and personality development (6th ed, Vol. 3,pp. 933-1002). New York: Wiley.

Wigfield, A., Muenks, K., \& Rosenzweig, E. Q. (2015). Children's achievement motivation in school. In C. M. Rubie-Davies, J. M. Stephens \& P. Watson (Eds.), The Routledge international handbook of social psychology of the Classroom (pp. 9-20). New York, NY: Routledge.

Woltman, H., Feldstain, A., MacKay, J. C., \& Rocchi, M. (2012). An introduction to hierarchical linear 
modeling. Tutorials in quantitative methods forpsychology, 8(1), 52-69.

Zanobini, M., \& Usai, M. C. (2002). Domain-specific self-concept and achievement motivation in the transition from primary to low middle school. Educational Psychology, 22(2), 203-217. doi: $10.1080 / 01443410120115265$. 